\title{
Entre a greve e o locaute: os ethè em disputa pelo lugar de verdade nas cenografias ideológicas que paralisaram o Brasil
}

\author{
Between strike and locaute: ethè in dispute \\ for the place of truth in the ideological \\ scenographies that paralyzed Brazil
}

\author{
FERNANDO SIMÕES ANTUNES JUNIORa \\ Universidade Feevale, Programa de Pós-Graduação em Processos e Manifestações Culturais. Novo \\ Hamburgo - RS, Brasil \\ ERNANT CESAR DE FRETTA S \\ Universidade Feevale, Instituto de Ciências Sociais Aplicadas. Novo Hamburgo - RS, Brasil \\ Universidade de Passo Fundo, Programa de Pós-Graduação em Letras. Passo Fundo - RS, Brasil
}

\section{RESUMO}

A paralisação dos rodoviários no Brasil em 2018 colocou em disputa forças ideológicas que usam o medo para se perpetuarem no imaginário. Neste artigo, daremos ênfase a notícias que caracterizaram a paralisação como um locaute, em contraposição ao cenário de greve pretendido pela categoria. O objetivo é analisar o discurso midiático que favoreceu uma cenografia pretendida pelo governo. Como aporte teórico, são mobilizados estudos sobre formação de crença, de Bateson; emoções, de Damásio e Ekman; ideologia da desconexão, de Taylor; e semiologia, do círculo de Bakhtin. O marco teórico de análise do discurso é o da escola francesa, de Dominique Maingueneau. A pesquisa é do tipo exploratório, bibliográfica, com abordagem qualitativa.

Palavras-chave: Comunicação, ideologia, cenografia, ethos discursivo, discurso político

\section{ABSTRACT}

The road stoppage that occurred in Brazil in 2018 put in dispute ideological forces that use fear to perpetuate themselves in the collective imagination. In this article, we will emphasize the news that characterized the stoppage as a lockout, as opposed to the strike intended by the category. Our objective is to analyze the media discourse that favored the scenography intended by the government. Studies on belief formation, by Bateson; on emotions, by Damásio (2000) and Ekman (2011); ideology of disconnection, by Taylor; and the semiotic dimension of the Bakhtin Circle (Volóchinov, 2017) are used as theoretical contribution. The French school of discourse analyses by Dominique Maingueneau is the main theoretical framework (2008a, 2008b, 2013). The research is exploratory, bibliographical, with a qualitative approach.

Keywords: Communication, ideology, scenography, discursive ethos, political discourse

${ }^{a}$ Doutor em Comunicação Social pela Pontifícia Universidade Católica do Rio Grande do Sul (Porto Alegre/ Brasil). Pós-doutorando em Processos e Manifestações Culturais pela Universidade Feevale. Orcid: https://orcid. org/0000-0002-0626-0554. E-mail: feuantunes@gmail.com

${ }^{\mathrm{b}}$ Doutor em Letras pela Pontifícia Universidade Católica do Rio Grande do Sul (Porto Alegre/Brasil). Professor na Universidade Feevale e na Universidade de Passo Fundo. Orcid: https://orcid.org/00000002-8920-9446. E-mail: ernanic@feevale.br 
${ }^{1}$ Um aportuguesamento da expressão em inglês lockout, que na tradução livre significa bloqueio, mas que representa uma prática proibida pela legislação brasileira, em que a parte patronal das relações trabalhistas se recusa em ceder aos trabalhadores os instrumentos de trabalho necessários para a sua atividade. Ao contrário da greve, que ocorre com a paralisação dos trabalhadores, o locaute se dá pela paralisação dos empregadores.

\section{INTRODUÇÃO}

7 NTRE OS DIAS 21 e 31 de maio de 2018, o Brasil enfrentou uma paralisação de serviços básicos sem precedentes desencadeada por uma greve de caminhoneiros que reivindicava redução no preço do óleo diesel. Estradas foram bloqueadas e a circulação de itens essenciais como alimentos, gás de cozinha e combustíveis foi totalmente comprometida. Serviços básicos, como transporte público e recolhimento de lixo, foram prejudicados. A falta de abastecimento obrigou o comércio a fechar as portas, causando um prejuízo estimado em quase cem bilhões de reais em setores fundamentais para a economia. O impacto das perdas levou economistas do centro do país a baixarem as projeções de aumento do Produto Interno Bruto (PIB) de 3\% para 2\% em 2018 (Silva, 2018). Além de mostrar total dependência do transporte rodoviário, a paralisação também colocou em evidência duas palavras que marcaram as disputas ideológicas que hoje ainda pairam no imaginário coletivo brasileiro. Afinal, a manifestação tratou-se de um ato de greve, previsto na Constituição Federal, ou de um locaute ${ }^{1}$, movimento considerado ilegal pela legislação do país? A disputa pelo lugar de verdade entre estas duas palavras criou dúvidas na população sobre apoiar ou não o movimento dos rodoviários. A mutação dos ethè (Maingueneau, 2013) dos atores envolvidos nas cenas enunciativas que se formaram no período, orquestrada por ideologias que usam o medo como elemento de persuasão, colocou governo, manifestantes e imprensa em um cenário de conflito ideológico que acirrou ainda mais os ânimos entre setores da sociedade já conturbados pelos sucessivos eventos pós-impeachment.

Outras tentativas de rotular a paralisação como "um pedido de intervenção militar" ou "o começo de uma ditadura comunista" colocaram o Governo Federal, os sindicatos patronais dos rodoviários e os caminhoneiros em uma disputa de simulacros. No meio da indefinição, a sociedade brasileira viu definhar sua capacidade de agir, reagir e resistir a um impasse desta magnitude, transformando o episódio num dos mais marcantes da história política e econômica do país.

A paralisação dos rodoviários mostrou que, além de estar refém de um sistema de transporte precarizado e combalido, a sociedade brasileira possui frágeis bases de sustentação das instituições democráticas, que são constantemente ameaçadas por retóricas que usam o medo como mecanismo de controle do imaginário coletivo. E é esta característica que nos leva a revisitar aspectos do episódio à luz de alguns conhecimentos sobre significação, emoções e discurso. Para isto, será analisado um dos inúmeros construtos simbólicos jornalísticos sobre a paralisação, mais especificamente uma reportagem produzida pela emissora de canal fechado GloboNews, que buscou retratar as motivações da suposta greve segundo os indícios apresentados pelo governo que caracterizariam a paralisação como 
sendo um locaute. Diante desse corpus, surgem algumas perguntas que dão norte a toda a análise aqui proposta. Teria a GloboNews usado as estratégias retóricas de eliciação do medo, uma característica da chamada ideologia da desconexão (Taylor, 2006)? Se sim, que cenografias emergem desta interdiscursividade? E que ethè se apresentam em disputa para efeitos de persuasão e ressignificação da audiência? O objetivo do trabalho é analisar o discurso midiático em torno do vídeo, que contribuiu para a concepção de uma cenografia pretendida pelo governo, em contraposição ao cenário de greve geral defendido pelos sindicatos. Como aporte teórico, utilizam-se estudos sobre a formação da crença de Bateson (1987), em interface com os estudos das emoções de Damásio (2000) e Ekman (2011), ancorados na semiologia do círculo de Bakhtin (Volóchinov, 2017) e no conceito de ideologia da desconexão, de Michael Taylor (2006). O marco teórico principal de análise do discurso é o da escola francesa, em especial as categorias de cenografia e ethos de Dominique Maingueneau (2008a, 2008b, 2013). A pesquisa é do tipo exploratório, bibliográfica, com abordagem qualitativa.

Com base nos aportes teóricos supracitados, começaremos este artigo compreendendo como as emoções operam na construção dos significados e na formação das ideologias. Na segunda parte, vamos conceituar a ideologia da desconexão e sua relação com cenografias discursivas que eliciam o medo. E por fim, analisaremos os ethè em disputa nesta cenografia a partir da análise do corpus já especificado.

\section{AS EMOÇÕES E OS SIGNOS IDEOLÓGICOS}

As crenças em disputa que culminaram na greve dos caminhoneiros no Brasil exigem que se faça, primeiro, uma breve conceituação do termo ideologia. Neste trabalho, tratamos ideologia como um conjunto de crenças e significações compartilhadas por grupos de pessoas que definem os filtros com os quais elas percebem o mundo. Os teóricos do círculo de Bakhtin (Volóchinov, 2017) preconizaram, ainda no começo do século XX, que tudo que é ideológico possui uma significação. Ou seja, conecta algo percebido fora do sujeito com uma experiência interna, vivenciada através de um signo. Volóchinov (2017) é categórico ao defender que "onde não há signo, também não há ideologia" (p. 91). Qualquer objeto físico perceptível aos cinco sentidos humanos pode ser percebido como a imagem de algo que ganha distintos significados, sem deixar de ser uma parte da realidade material, mas refratando ou refletindo outras realidades. Comenta Volóchinov (2017): 
O signo não é somente uma parte da realidade, mas também reflete e refrata uma outra realidade, sendo por isso mesmo capaz de distorcê-la, ser-lhe fiel, percebê-la de um ponto de vista específico e assim por diante. As categorias de avaliação ideológica (falso, verdadeiro, correto, justo, bom etc.) podem ser aplicadas a qualquer signo. O campo ideológico coincide com o campo dos signos. Eles podem ser igualados. Onde há signo há também ideologia. Tudo o que é ideológico possui significação sígnica. (p. 93)

Os teóricos do círculo de Bakhtin chegaram ao entendimento de que os processos de compreensão de qualquer fenômeno ideológico não podem ser realizados sem a participação de um discurso interior, em que todas as manifestações da criação ideológica, isto é, todos os outros signos não verbais são envolvidos pelo universo verbal, emergem nele e não podem ser nem isolados, nem separados dele por completo. Por isto defendem que as ideologias e os regimes sociopolíticos se conectavam através das interações verbais, elementos de análise daquilo que os marxistas chamam psicologia social.

Gregory Bateson (1987), ao propor um modelo dialógico na compreensão da comunicação humana, sabendo que qualquer significação exige uma estrutura linguística interna, defende que o sistema de crenças que direciona o pensar humano não é um sistema rígido. Está em constante movimento, se adapta ao meio, flexibiliza conceitos, porém tem como base as estruturas profundas que se formam ainda nos primeiros anos de vida, e que vão determinar capacidades, comportamentos e reações. Tais estruturas, que servem como diretrizes inconscientes, em grande parte seriam determinadas pelas emoções.

Quando Gregory Bateson (1987) deparou com o trabalho lógico e matemático de Bertrand Russel, formulou o que chama níveis lógicos de aprendizagem e mudança. Robert Dilts (2014) estudou a hierarquia destes níveis lógicos e percebeu que a função de cada um deles consiste em sintetizar, organizar e dirigir as intenções do nível inferior. Sugere, portanto a existência de uma estrutura lógica que determina o funcionamento da aprendizagem e de mudanças comportamentais baseada numa hierarquia do que chamou níveis de processamento e organização, ou níveis neurológicos. São seis níveis, em que os mais baixos no processamento hierárquico são comandados e determinados pelos níveis mais elevados (Dilts, 2014).

O primeiro nível, ou o mais inferior, está relacionado às reações e aos impulsos emocionais sem qualquer uso da razão, frequentemente acionado quando deparamos com ambientes ou situações inesperadas. O segundo nível refere-se aos comportamentos, relacionados aos hábitos e condicionamentos. O terceiro 
nível abarca as capacidades, conjunto de aptidões adquiridas que determinam o que o sujeito é ou não capaz de fazer em suas interações com o mundo. As crenças, então, constituem o quarto nível, que estabelece diretrizes de tudo o que pode ser uma verdade e tudo que não pode. Acima das crenças, Dilts (2014) refere ainda dois outros níveis, sendo o quinto o que ele chama de missão, que define a identidade do sujeito, dando sentido à vida e à individualidade; e o sexto nível, o qual denomina de visão, relacionado à noção de pertencimento a algo maior, à espiritualidade e aos questionamentos filosóficos da humanidade, responsável por dar sentido à existência (Figura 1).

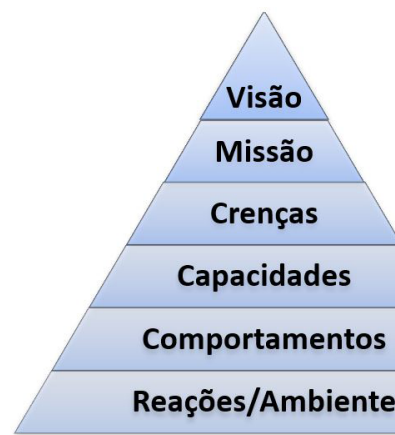

Figura 1. Níveis Neurológicos. Adaptado de Dilts (2014).

Qualquer mudança em um nível superior necessariamente irradia para baixo, precipitando alterações também dos níveis hierarquicamente inferiores. Como exemplo, imaginemos um bebê prestes a nascer. Seu sistema psíquico, ainda sem propriedades racionais, sabe instintivamente que o corpo se alimenta pelo cordão umbilical (crença/verdade) e, portanto, ainda não possui a capacidade de respirar (capacidades). Por óbvio, o hábito de respirar ainda não existe (comportamento), e tampouco este bebê reage à ausência de ar (reações/ambiente). A mudança abrupta de ambiente provocada pelo evento do nascimento faz o bebê lidar com uma situação extrema. O desconforto do choque térmico ativa um conjunto de emoções e sensações que vão desencadear processos orgânicos instintivos e inatos (missão) e, portanto, naturalmente pré-programados pelo organismo que o concebeu (visão). A nova necessidade de respirar, de se alimentar de oxigênio pelo ar que adentra aos pulmões, faz com que o recém-nascido comece a realizar os movimentos de inspiração e expiração trinta segundos após o parto (Lent, 2008). Assim sendo, toda esta cadeia de eventos "traumáticos" vai promover uma ressignificação no sistema de crenças do bebê. Por instinto, a crença de que "é preciso respirar para sobreviver" torna-se uma 
diretriz enraizada em seu inconsciente. É ela que possibilita a capacidade de respirar e fazer os movimentos necessários de inspiração e expiração para que o ar chegue aos pulmões e as moléculas de oxigênio voltem a alimentar a corrente sanguínea. Da mesma forma, as reações passam a obedecer esta nova diretriz para estabelecer os reflexos necessários a este processo vital de sobrevivência no novo ambiente em que o pequeno ser vai existir. O nível das crenças, portanto, seria a ponte conectiva que estabelece as relações e os modos de interação do indivíduo com o meio, determinando reações, comportamentos e aprendizagens, e seguindo uma lógica que obedeça a instintos individuais e coletivos dentro da trajetória cognitiva do sujeito. De forma dialógica, o meio vai atuar no crençário do sujeito, causando-lhe emoções e provocando reações diversas, culminando em reestruturações e ressignificações dentro de seu crençário em constante movimento.

O exemplo do funcionamento dos níveis neurológicos em um bebê é pertinente, pois permite a inferência de que a hierarquia dos níveis neurológicos é operante mesmo antes da formação da consciência e do desenvolvimento da capacidade linguística. O que muda quando desenvolve a linguagem é que o sujeito se torna capaz de atribuir códigos sentenciais para descrever os significados que dá aos universos interior e exterior. Isto é, formula frases que representam as diretrizes às quais seu sistema psíquico obedece. É quando o sistema de crenças substitui o código de diretrizes de um sentir instintivo por um conjunto de construções frasais cuja menor unidade é a palavra, que, segundo Volóchinov (2017), é o signo ideológico por excelência, pois está carregada de significados.

A seguir, vamos esclarecer como os dispositivos emocionais atuam na significação das coisas, e como esta significação vai estruturar crenças que vão cristalizar a ideologia nas relações dialógicas entre os indivíduos.

\section{Interdiscursividade e simulacros da realidade}

Vivemos a realidade que nosso cérebro cria a partir destas percepções filtradas do mundo exterior. Ou seja, há uma seleção das informações percebidas pelos cinco sentidos. Aquelas que são interessantes segundo nossas crenças, valores, pressuposições, entre outros fatores, são simplificadas para compor nossos filtros, que se manifestarão através de nosso arcabouço comunicativo.

Dominique Maingueneau (2008b), em sua gênese dos discursos, corrobora essa percepção ao constatar que a realidade pura, aquilo que Platão chama de verdade ideal, nos seria inalcançável, pois nossos filtros, resultado de uma 
interdiscursividade anterior à própria existência do indivíduo, atuam de forma a construir um simulacro da verdade, cuja percepção se manifesta pelo discurso.

Isto quer dizer que o interdiscurso precede o discurso, e é regido por um sistema de restrições semânticas globais que se manifesta pelo fato de restringir ao mesmo tempo todos os planos discursivos: vocabulário, temas, intertextualidade e instâncias de enunciação. O discurso aqui referido por Maingueneau (2013) não é apenas um conjunto de textos, mas uma prática discursiva. $\mathrm{O}$ sistema de restrições semânticas torna os textos comensuráveis com a rede institucional de um grupo, que a enunciação ao mesmo tempo supõe e torna possível. Isso faz da prática discursiva uma prática intersemiótica em que outros domínios semióticos, como o pictórico, o televisivo, o musical etc., coexistem. Uma formação discursiva revela-se, assim, como esquema de correspondência entre campos à primeira vista heterônimos.

Essa interdiscursividade semiótica que vai compor nossa rede de crenças estará calcada, segundo Peirce (2008), em motivadores emocionais inconscientes que nos obrigam a aderir a determinadas verdades para alcançar estados de espírito mais favoráveis. O próprio processo de semiose, ou seja, de produção de significado e sentido dos signos, depende do que Peirce chama de "interpretante emocional", que gera sentimentos diante do signo. Somado ao interpretante energético, que corresponde a uma reação da mente, e ao interpretante lógico, que diz respeito à produção de um pensamento ou entendimento geral produzido pelo signo, o interpretante emocional dará o contorno ao significado e à sua significação, estabelecendo um crençário específico na psique de cada indivíduo (Colapietro, 2014). Alguns dos fundamentos que compõem a semiótica de Peirce, somados a pressupostos já vistos do pensamento sistêmico de Bateson (1987) e da interdiscursividade de Maingueneau (2013), ficam mais transparentes quando postos em interface com os estudos da neurociência.

Bandler e Grinder (2004) atestam que esse processo de significação é o princípio do que chamam de ancoragem. Para eles, âncora é qualquer estímulo sensorial capaz de eliciar um estado interno, de maneira automática, sem interferência do senso crítico. Tais estímulos passam a integrar uma estrutura emocional de significação e memória que pode ser eliciada sempre que são percebidos. Estímulos similares tendem a eliciar emoções similares, fundamentando uma espécie de condicionamento emocional (Ekman, 2011), como demonstra a Figura 2. 


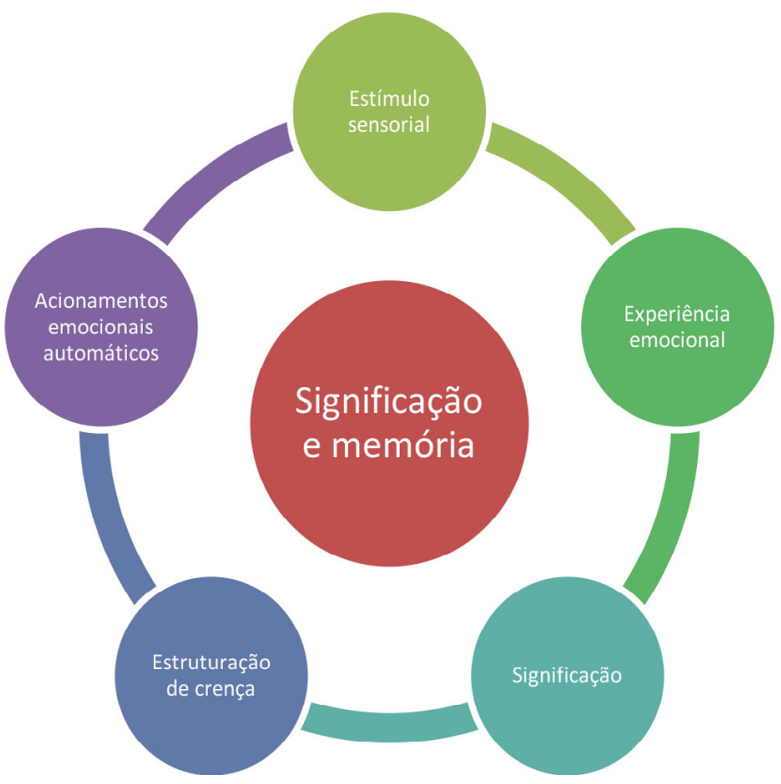

Figura 2. O processo de ancoragem. Reproduzido de Antunes Junior (2016, p. 41).

O que pode ser inferido a partir desses apontamentos é que, por mais que consideremos racionais os argumentos que nos façam defender ou optar por determinada ação ou visão de realidade, inconscientemente sempre existirão motivações emocionais preponderantes que alicerçam a construção ideológica do ser. Essas sustentam escolhas e nem sempre estão acessíveis à compreensão de nossa parte consciente, justamente porque obedecem a programações inatas ou mesmo condicionadas, que são alheias ao senso crítico. Peirce (2008) e Bandler e Grinder (2004), portanto, defendem que o significado inevitavelmente está ancorado em emoções e sentimentos. Essa percepção nos leva aos estudos do círculo de Bakhtin (Volóchinov, 2017), que se apoia na premissa de que onde há um signo, há uma ideologia. Tal escola de pesquisadores russos conceitua ideologia pelo viés marxista, enquanto uma superestrutura que impera no psicológico e opera como um filtro à percepção do mundo, cuja menor unidade seria o signo. "O signo não é somente uma parte da realidade, mas também reflete e refrata uma outra realidade, sendo por isso mesmo capaz de distorcê-la, ser-lhe fiel, percebê-la de um ponto de vista específico e assim por diante" (Volóchinov, 2017, p. 93).

Nessa conceituação, definem que o campo ideológico coincide com o campo dos signos, e podem ser igualados, pois o caráter sígnico é um traço comum a todos os fenômenos ideológicos. Numa compreensão mais abrangente de 
ideologia, que a vê enquanto um conjunto de crenças e valores transmitidos nas práticas culturais, políticas e econômicas de uma dada sociedade, Volóchinov (2017) defende que onde há um signo, há uma ideologia. Ao mesmo tempo, entende que a ideologia é um fato da consciência, ou seja, "o corpo exterior do signo é apenas um envoltório, apenas um meio técnico para a realização do efeito interno que é a compreensão" (p. 95). Tal compreensão se dá na relação com outros signos, cujos significados anteriores dialogam com o signo presente, resultando, assim, em novos signos e significações, ao que complementa:

Tal cadeia ideológica se estende entre consciências individuais, unindo-as, pois o signo surge apenas no processo de interação entre consciências individuais. E a própria consciência individual está repleta de signos. Uma consciência só passa a existir como tal na medida em que é preenchida pelo conteúdo ideológico, isto é, pelos signos, portanto apenas no processo de interação social. (Volóchinov, 2017, p. 95)

A relação da ideologia - que é constituída de interdiscursividades - com as emoções, portanto, se cristaliza nas interações sociais, haja visto que são as emoções os mecanismos que nos colocam em estados de ação para a interação com o meio. É a partir da percepção do estado de espírito do outro, e dos discursos que o outro profere ou representa em um dado contexto, que as emoções se ativam e interferem na significação. Para uma compreensão analítica do fenômeno que Michael Taylor (2006) chama "ideologia da desconexão", no qual nossa percepção de mundo é subvertida do campo moral para o campo econômico, evocaremos os conceitos de cenografia e ethos, de Maingueneau (2013), que devem nortear a análise deste estudo. No entanto, antes é preciso entender como a ideologia da desconexão se fundamenta na emoção do medo.

\section{A IDEOLOGIA DA DESCONEXÃO E AS CENOGRAFIAS DO MEDO}

Antes de entrar nas características que definem a ideologia da desconexão, é importante ter um entendimento sobre alguns estudos acerca das emoções, em especial a emoção do medo. Segundo Ekman (2011), nenhuma emoção foi tão estudada quanto essa, justamente por ser um estado de tomada rápida de decisões. $\mathrm{O}$ interesse por esse estado natural de alerta, que é acionado quando o organismo depara com uma possível situação de desconforto, dor e, em último caso, aniquilamento, talvez se explique por ser o medo uma emoção que nos condicionou a respostas físicas e psíquicas que praticamente determinaram nosso modo de vida na atualidade (Damásio, 2000). Da sociologia à 
neurociência, passando pelas ciências do comportamento e da comunicação, o medo, que se manifesta no nível neurológico das reações (Dilts, 2014), ativado mediante determinados ambientes ou cenas enunciativas, é a origem dos sistemas que regem o convívio social, tanto no ocidente quanto no oriente. Bauman (2009) relembra que os medos modernos tiveram início no que ele denomina "consequências individualistas da redução do controle estatal" (p. 19). Foi quando uma capacidade imemorial de estabelecer empatia pelo outro passou a ser substituída por laços artificiais embasados na competição. A inquietação sobre a ameaça constante que compõe o ambiente competitivo teria, na visão de Bauman, colocado o mundo em uma espiral de fobias em relação ao outro, ao que é diferente e ao que é estranho. Esta tensão constante, ao mesmo tempo em que é a consequência, é o combustível da sociedade do medo em uma relação cíclica de retroalimentação. Ela nos impulsiona a estabelecer limites e fronteiras, a erguer muros e barreiras, sempre nos afastando de qualquer oportunidade de conhecer mais a fundo o que foge à zona de conforto delimitada por nossa rede de crenças.

É o medo que determina como deve ser a arquitetura das cidades, como devemos nos locomover, no que devemos investir, que roupa devemos usar e até que comportamentos devemos adotar. Determina também quais devem ser as prioridades políticas e econômicas, pois, em frente a qualquer ameaça à segurança social, o medo é eliciado nas narrativas e construtos simbólicos que visam promover a integração da sociedade. Como mostrou a greve dos caminhoneiros no Brasil em 2018, o medo de ficar sem combustível, de perder as opções de consumo, enfim, o medo de ter que se adaptar a novas rotinas, pode gerar uma infinidade de lucros políticos e comerciais quando confrontado com promessas de segurança. Como destaca Bauman (2009),

A segurança pessoal tornou-se muito importante, talvez o argumento de venda mais necessário para qualquer estratégia de marketing. A expressão "lei e ordem”, hoje reduzida a uma promessa de segurança pessoal, transformou-se num argumento categórico de venda, talvez o mais decisivo nos projetos políticos e nas campanhas eleitorais. A exposição das ameaças à segurança pessoal é hoje um elemento determinante na guerra pelos índices de audiência dos meios de comunicação de massa (incrementando assim o sucesso dos dois usos, político e mercadológico, do capital do medo). (p. 55)

A sensação de constante ameaça na sociedade competitiva capitalizada pelo medo gera dois encaminhamentos possíveis para a psique humana, duas rotas antagônicas, as quais Giddens (1989) define como cultura da segurança e cultura 
de risco. A primeira serve para legitimar os novos laços de sociabilidade propostos pela sociedade de consumo e a ciência e a tecnologia como caminhos seguros e benéficos, instigando a adesão às instituições, produzidas e produtoras, das grandes estruturas da sociedade. A segunda recobre-se de cautelas ao enfatizar os riscos presentes e futuros à individualidade e à coletividade impostos pelo progresso e sua provável capacidade de minar a existência e nos conduzir a calamidades e problemas de difícil solução, senão ao próprio apocalipse, dando novos e mais sombrios contornos aos medos arquetípicos (Bartolli Filho, 2012). Na dinâmica de ora amedrontar e ora oferecer segurança, a indústria e o comércio de alimentos, de medicamentos, de planos de saúde, de seguros, e até "da fé" se fortalecem por estarem constantemente desenvolvendo novos produtos ou serviços que tentam remediar aquilo que nos ameaça e causa temor. A publicidade recorre frequentemente ao medo para elaborar discursos e criar novas necessidades em vez de resolver ou solucionar as já existentes. A partir do temor induzido pelas ameaças, sejam elas implícitas ou explícitas, o receptor tende a aceitar as soluções apresentadas, mesmo que seja "pela dúvida" (Ferrés, 1998).

Essa constante eliciação do medo para fazer girar a roda de consumo trouxe consequências na vida globalizada e hipermidiatizada, tornando-se um dos principais motores daquilo que Michael Taylor (2006) chama ideologia da desconexão, ou da desintegração. Tem como base o conjunto de conceitos e dogmas perpetuados pelo capitalismo, no qual o homem está à parte, desconectado do outro, da natureza e do todo. Por estar estruturada numa teoria econômica neoclássica, tal ideologia deixa de lado tudo aquilo que nos torna humanos para se apoiar em uma base axiomática estruturada a partir da visão de um economista. Estabelecer, portanto, cenografias midiáticas que despertem ou provoquem medo, faz parte dos mecanismos que acionam a roda do consumo. E mercantilizar as relações resultantes desse medo nos leva a ignorar os sentimentos coletivos para priorizar a individualidade, nos tornando seres desconectados não apenas uns dos outros, mas desconectados dos instintos inatos básicos de alteridade e empatia.

O princípio fundante da ideologia da desconexão começa, portanto, com a dicotomia insegurança/segurança e sobrepõe-se às incoerências resultantes desse processo. Taylor (2006) defende que a ideologia da desconexão, resultado da monetarização de valores e sentimentos, promove uma mercantilização das relações, substituindo a força de valores pela força de mercado. Para exemplificar, ele narra um famoso experimento de creches realizado em Haifa, em 1998, que ilustra o uso de incentivos e sanções econômicas como mediadores das relações humanas. Um problema do qual a maioria das creches daquela localidade sofre, segundo o exemplo, é a dificuldade em reunir os pais das crianças para reuniões 
de classe. A solução óbvia dos economistas foi introduzir uma multa para os retardatários. Porém, ao invés de diminuir o número de adultos atrasados, mais pais chegaram atrasados com a aplicação da multa. Taylor (2006) argumenta que a introdução de incentivos monetários provocou a mudança de uma percepção moral para uma conceituação econômica do comportamento. Isso porque, ao pagar a multa, os pais entendiam ter "sanado" a dívida com a creche e com seus filhos. Disso, duas conclusões ficaram óbvias: a primeira é que a motivação moral pode ser mais poderosa do que econômica; e a segunda, é que mercantilizar relações sociais pode eliminar o senso de comunidade e provocar uma ausência de moralidade, a qual desenvolve importante papel nos processos empáticos.

A desconexão da ideologia dominante, segundo Taylor (2006), começa dentro de nós mesmos, entre as partes que constituem nossa psique, e que entram em colapso quando encontram caminhos distintos e antagônicos para se desenvolver. Quando há uma mercantilização, monetarização ou comercialização de valores e sentimentos, as incoerências tornam-se toleráveis pelo benefício econômico que proporcionam.

Como proposto na introdução deste artigo, para percebermos na prática como a ideologia da desconexão opera em construtos simbólicos da mídia, vamos utilizar os conceitos de cenografia e ethos, de Dominique Maingueneau (2008a, 2008b, 2013), para fazer uma análise discursiva de uma reportagem veiculada no canal GloboNews sobre a greve dos caminhoneiros que paralisou o Brasil em maio de 2018.

\section{ETHÈ EM DISPUTA NA CENOGRAFIA DO MEDO}

Quando relaciona o poder do contexto sobre os enunciados, Maingueneau (2013) defende que todo ato comunicativo é assimétrico, pois cabe a quem interpreta reconstruir seu sentido através da mobilização de saberes diversos, de forma a construir um contexto que não é dado pelo enunciador, mas que paira na cenografia discursiva. $\mathrm{O}$ autor lembra que qualquer enunciação é constituída de três cenas. A cena englobante, que revela o tipo de discurso (jornalístico, religioso, político etc.); a cena genérica, que trata do gênero do discurso (no jornalismo, a entrevista; no político, a propaganda eleitoral; no religioso, a pregação etc.); e a cenografia, que é a instituição de uma cena que vai sendo validada pela própria enunciação.

O valor pragmático do enunciado, ou seja, a intenção que une enunciador e destinatário, vai exigir interpretações de ambas as partes, que se constituirão em materialidades discursivas dialógicas. Tais materialidades vão revelar, além do conteúdo do discurso, a personalidade do enunciador, o ethos por trás da 
enunciação, com pistas sobre sua personalidade e seu perfil psicológico, bem como fazer emergir uma instância subjetiva que desempenha o papel de fiador do que é dito (Amossy, 2011; Maingueneau, 2013).

$\mathrm{O}$ aporte teórico aqui apresentado sugere que a ideologia da desconexão está presente nas materialidades discursivas a serem analisadas, e se revela por cenografias construídas para eliciar o medo no espectador a partir da emergência de determinados ethè. São estas materialidades discursivas que revelam as cenas ideológicas presentes na greve dos caminhoneiros. O construto discursivo a ser analisado é a reportagem "Cade investiga vídeo de 2017 que mostra consequências de possível greve de caminhoneiros" (GloboNews, 2018), veiculada no dia 26 de maio de 2018, pelo "Jornal das Dez", do canal fechado GloboNews. Apesar de diversos veículos, inclusive da TV aberta, exibirem reportagens semelhantes, a motivação para esta análise da matéria da GloboNews é porque o jornal trouxe a cobertura mais extensa dentre todos os noticiários da Rede Globo; e apresenta, dentro da cena englobante do jornalismo, algumas cenas genéricas variadas, como reportagens, entrevistas e comentários ao final das matérias jornalísticas, o que deixa mais clara a cenografia ideológica da emissora sobre os fatos do dia.

Para a análise, colocamos em interface os procedimentos metodológicos da análise de discurso com os conceitos de cenografia e ethos (Maingueneau, 2008a, 2008b, 2013), amparados nos conceitos de significação e ideologia de Bakhtin (Volóchinov, 2017), e nas funções sistêmicas das emoções (Damásio, 2000) para fins de ressignificação de crenças (Bateson, 1987; Dilts, 2014). Tais interfaces tipificam esta pesquisa como de caráter exploratório, bibliográfico, com abordagem qualitativa.

Parte-se do pressuposto de que, conforme Maingueneau (2013), o construto simbólico da GloboNews se constitui a partir de uma interdiscursividade anterior, carregada de signos ideológicos cuja proposição simbólica visa acionar interpretantes emocionais, energéticos e lógicos (Bandler \& Grinder, 2004; Peirce, 2008). A finalidade seria fazer emergir novas cenografias que eliciam o medo, e das quais emergem novos ethè que entrarão em disputa pelo lugar de verdade no imaginário coletivo.

\section{ANÁlISE}

A construção noticiosa da GloboNews em análise deu espaço à suspeita de que a paralisação dos caminhoneiros, ocorrida em maio de 2018, poderia ter motivações espúrias, ou seja, não dignas da empatia do público interpretante. Afinal, se a paralisação estivesse ocorrendo não por uma necessidade dos caminhoneiros, mas sim para atender aos interesses econômicos das empresas empregadoras, 
o fator motivador deixaria de ser uma questão social para se tornar um embate entre empresários do setor e governo. A peça publicitária produzida por uma das entidades patronais dos caminhoneiros como indicativo de um prenúncio da greve, no caso, um vídeo institucional da Federação dos Transportadores de Carga do Estado de São Paulo (FETCESP, 2017) seria, segundo o governo, um indício de que não se tratava de greve, mas locaute. Tal construção trouxe à tona o dilema de Taylor (2006), de que a mercantilização das relações humanas deteriora nossa percepção moral sobre o outro, em que o bem-estar individual e coletivo é sobrepujado pelos números da economia, utilizados para criar alarde e sensação de insegurança (Damásio, 2000). Tal construto foi apresentado no quarto dia de greve, o que nos leva a perceber as interdiscursividades que o precederam.

O aumento do dólar e do preço do petróleo no mercado internacional, que passaram a servir de parâmetros diários para oscilação do preço do combustível vendido nas refinarias brasileiras desde 2016 (“Greve dos caminhoneiros", 2018), levou caminhoneiros insatisfeitos com a situação a interromperem o trânsito em rodovias de ao menos dezessete estados da federação em 21 de maio de 2018. Nos dois dias subsequentes, a manifestação ganhou apoio e alcançou 24 estados, colapsando alguns setores da indústria e da economia. Os efeitos da paralisação, a essa altura, incluíam redução de frotas de ônibus nas grandes cidades, falta de combustíveis, disparada de preços em postos de gasolina, cancelamento de aulas em universidades, voos ameaçados por falta de combustível, prateleiras vazias em supermercados e centros de abastecimento e a interrupção da produção em fábricas.

Foi em meio a esse contexto que o Governo Federal anunciou um acordo, com parte dos representantes da categoria, para suspender a greve. $\mathrm{O}$ acordo incluiu, entre outros pontos, a promessa de atender a doze reivindicações dos caminhoneiros, entre elas zerar impostos sobre o diesel e baixar em $10 \%$ o preço do combustível nas refinarias por trinta dias. Mas mesmo depois da negociação, a paralisação dos caminhoneiros continuou, desafiando a cenografia resolutiva e apaziguadora que o Governo Federal tentou construir.

Os acontecimentos em torno da greve dos caminhoneiros, como o descumprimento do acordo firmado para acabar com a paralisação, assumido pela categoria, colocou em xeque o que Maingueneau (2013) chama de "lei superior do discurso" (p. 35), que é o princípio de cooperação.

Tal abalo gerou instabilidade institucional, na qual o governo de Michel Temer demonstrou ter pouco poder de negociação para normalizar empresas e serviços. Isso serviu como gatilho para acirrar o clima emocional nas redes sociais, o que demonstrava um agravamento das incertezas por parte da população. O cenário já não permitia perceber veracidade nos discursos, onde os 
explícitos e os implícitos ficaram confusos, e as palavras incorriam em múltiplas significações (Volóchinov, 2017). O ethos do então presidente Michel Temer, enquanto construção de uma imagem de si como um negociador eficaz, abala-se e passa para a de um presidente sem qualquer controle sobre a situação.

Para tentar contornar a situação, um novo discurso que já pairava em alguns veículos da imprensa é endossado pela alta cúpula do governo: o de que a paralisação dos caminhoneiros não seria um ato de greve, mas sim um locaute. Um dos argumentos usados para justificar tal percepção era que o vídeo da FETCESP, mais do que uma peça institucional, seria, segundo a argumentação difundida pelo governo, um indício de que a paralisação foi premeditada pelas entidades patronais. Tal cenografia propunha deslocar o sentimento de repulsa (Damásio, 2000) da população em relação ao governo para as entidades patronais e empresas transportadoras. A tentativa de ressignificar o vídeo da FETCESP não mais como uma defesa da categoria, mas sim como um vídeo que deixa implícitas ameaças de paralisação, caracteriza aquilo que Maingueneau (2013) chama deslocamento midiológico, quando um discurso é deslocado de seu contexto midiático original para ser transmitido em outra plataforma. No caso em estudo, um vídeo institucional produzido por uma entidade de classe para defender seus interesses é deslocado para telejornais de grande circulação enquanto prova da organização patronal por trás da paralisação.

Utilizando cenas validadas (Maingueneau, 2013) que acentuam o clima conspiratório de que forças patronais estariam por trás da greve, e que eliciam o medo pela instabilidade política e econômica em que o país se encontrava (Bartolli Filho, 2012; Damásio, 2000), a reportagem "Cade investiga vídeo de 2017 que mostra consequências de possível greve de caminhoneiros" (GloboNews, 2018), veiculada no dia 26 de maio de 2018, pelo "Jornal das Dez" do canal pago GloboNews, propõe uma narrativa que favorece a interpretação governista em relação à greve. Ao fazer uso de estereótipos e descontextualizar o vídeo da FETCESP, a equipe jornalística da GloboNews torna-se fiadora do discurso adotado pelo Governo Federal. No vídeo, a âncora do telejornal, Bete Pacheco (Figura 3), aparece com o cenário do "J10" ao fundo, e anuncia:

A Polícia Federal está investigando se empresários estão por trás da greve dos caminhoneiros, e já abriu 37 inquéritos. O Conselho Administrativo de Defesa Econômica também está apurando um vídeo divulgado pela Federação das Empresas de Transporte de São Paulo. (GloboNews, 2018)

O tom de seriedade na fala da jornalista (Damásio, 2000; Maingueneau, 2013), associado à quantificação de inquéritos abertos para investigar a greve (Taylor, 
2006), revelam que a diretriz ideológica do construto simbólico (Volóchinov, 2017) recorre à eliciação do medo como estratégia de persuasão.

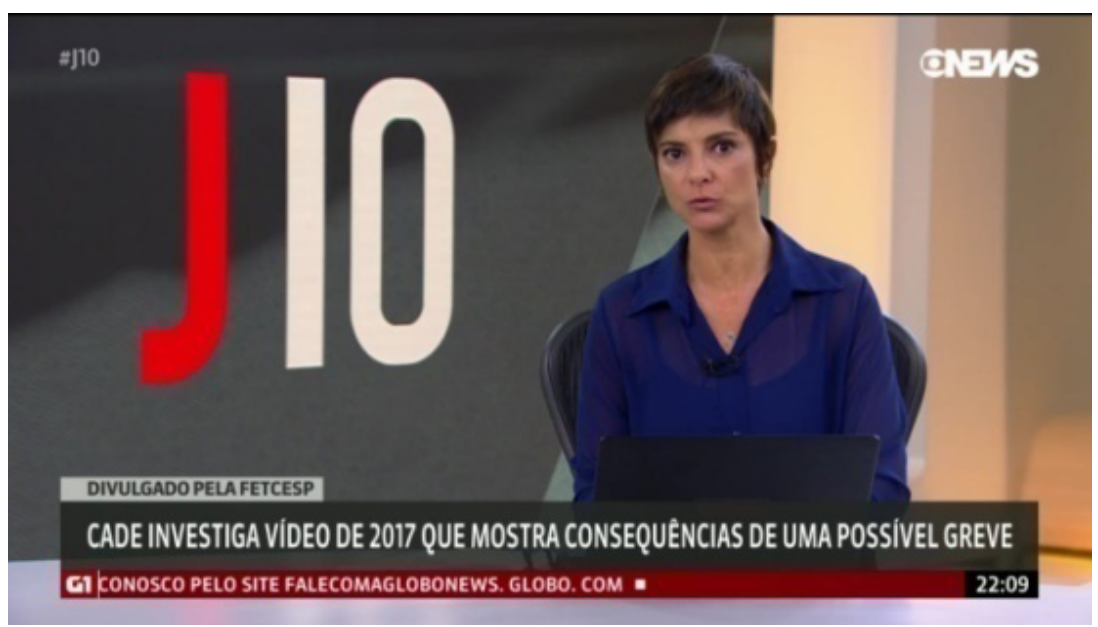

Figura 3. Âncora chama matéria sobre investigação do CADE. Imagem da reportagem da GloboNews (2018).

Tal incorporação induz a audiência a conferir um ethos ao seu fiador enquanto fiscal dos acontecimentos, atento às vicissitudes dos fatos, que agora pretende reescrever os significados da comunidade imaginária daqueles que comungam na adesão ao discurso de locaute (Maingueneau, 2013). A reportagem então começa com a imagem em computação gráfica representando uma tela de computador na qual aparece o site da FETCESP (Figura 4).

$\mathrm{Na}$ sequência, imagens da reunião entre o Governo Federal e representantes dos rodoviários assinando um acordo. No rodapé da tela aparecem duas legendas. Uma menor onde se lê "divulgado pela FETCESP" e uma maior com a frase "Cade investiga vídeo de 2017 que mostra consequências de uma possível greve” (Figura 5). 


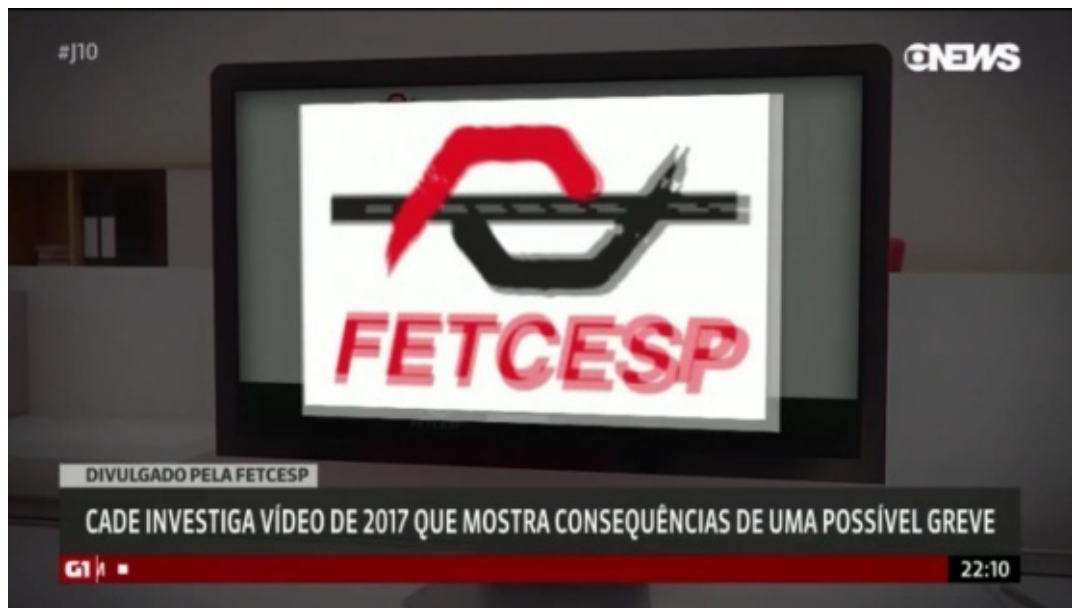

Figura 4. Computação gráfica ilustra site da FETCESP. Imagem da reportagem da GloboNews (2018).

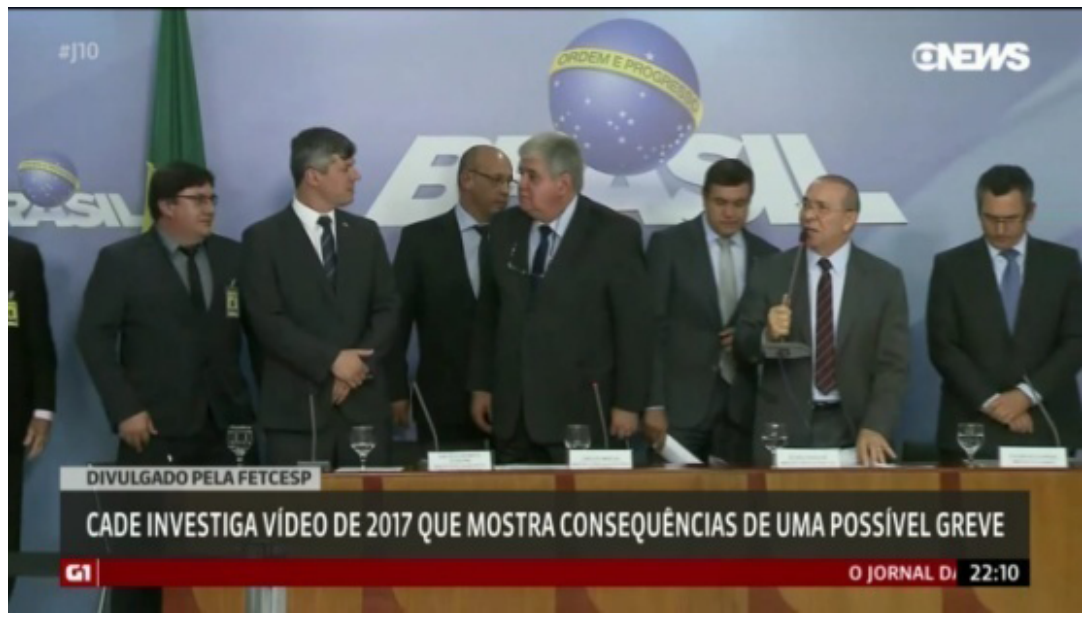

Figura 5. Computação gráfica ilustra site da FETCESP. Imagem da reportagem da GloboNews (2018).

A cenografia proposta intenta contextualizar a movimentação do governo para solucionar o problema da paralisação, em contraposição ao não cumprimento do acordo por parte dos caminhoneiros. Há uma tentativa de ressignificação de crença (Bateson, 1987; Dilts, 2014) para deslocar a percepção do público acerca de quem é a responsabilidade pela continuidade da greve. A voz de uma repórter em off dá sequência à reportagem: 
Uma das entidades investigadas é a Federação das Empresas de Transporte de Carga do Estado de São Paulo. Ela é uma das que assinaram um acordo com o governo na quinta-feira à noite. Neste vídeo, a Federação fala em sumir com caminhões e em caos pra todo lado, e descreve em detalhes as consequências de uma paralisação de caminhoneiros durante cinco dias. Uma situação muito parecida com a que acabou acontecendo no país. (GloboNews, 2018)

A narrativa da repórter desloca a intenção inicial do vídeo, de mostrar uma consequência da desvalorização da categoria rodoviária, para a interpretação desejada pelo governo, de que a entidade já falava "em sumir com caminhões e gerar caos para todo lado" (GloboNews, 2018). Trechos do vídeo institucional, então, são apresentados ao espectador; a voz da repórter silencia enquanto o vídeo ganha volume. Percebe-se uma música de tom intermitente, e então um narrador, em tom professoral, faz a defesa da categoria diante do que parece ser uma reclamação implícita do cidadão comum sobre os caminhões nas estradas. Diz o locutor:

Então os caminhões são um problema? Vamos sumir com eles por apenas cinco dias. Já no primeiro dia, você vai perceber que não foi uma boa ideia. Alimentos frescos essenciais esgotam nos mercados. Cartas se acumulam. Restaurantes reduzem seus menus. Obras param por falta de materiais. E as farmácias ficam sem medicamentos. Postos de gasolina já não têm combustível para vender. No campo, as produções estão estragando porque não há transporte. Os aeroportos são fechados, pois sem combustível, os aviões não podem decolar. O lixo se acumula por toda a cidade. Indústrias de vários segmentos já não conseguem produzir por falta de insumos. Agora, no quinto dia sem caminhões, o caos está por todo o lado. A sociedade entra em colapso. Não há transporte público, hospitais e escolas. As pessoas não conseguem seguir sua rotina. (GloboNews, 2018)

O discurso é acompanhado por imagens que ilustram o que está sendo narrado. Imagens de caminhões nas estradas ganham um efeito especial e os caminhões desaparecem. Uma estrada em movimento, em preto e branco, com velocímetros sobrepostos por computação, e uma legenda que cresce na tela fazendo a contagem dos dias sem caminhões, se intercala com imagens de produtos de supermercado e cartas nos correios, prateleiras de farmácias onde caixas de remédios desaparecem e postos de combustíveis fechando por falta de gasolina (Figura 6). 


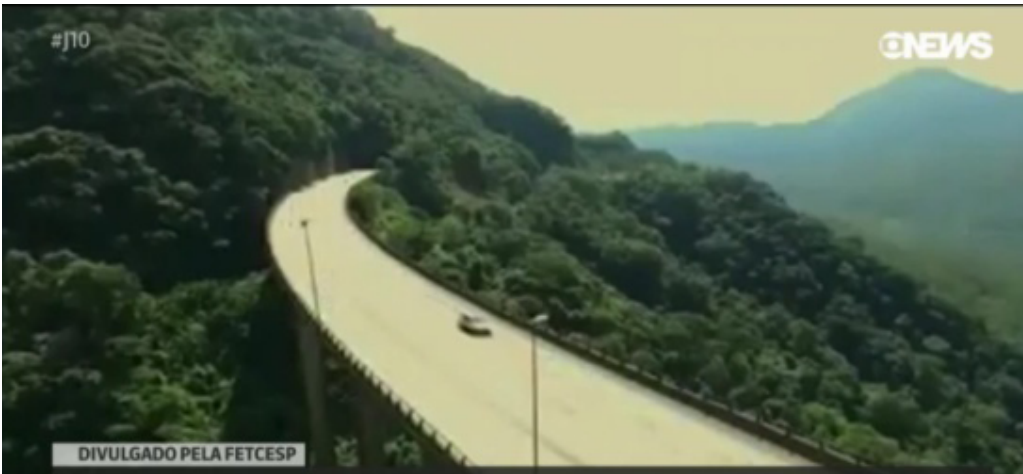

CADE INVESTIGA VIDEO DE 2017 QUE MOSTRA CONSEQUÉNCIAS DE UMA POSSIVEL GREVE

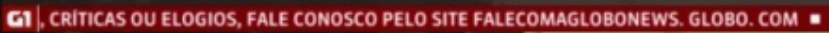
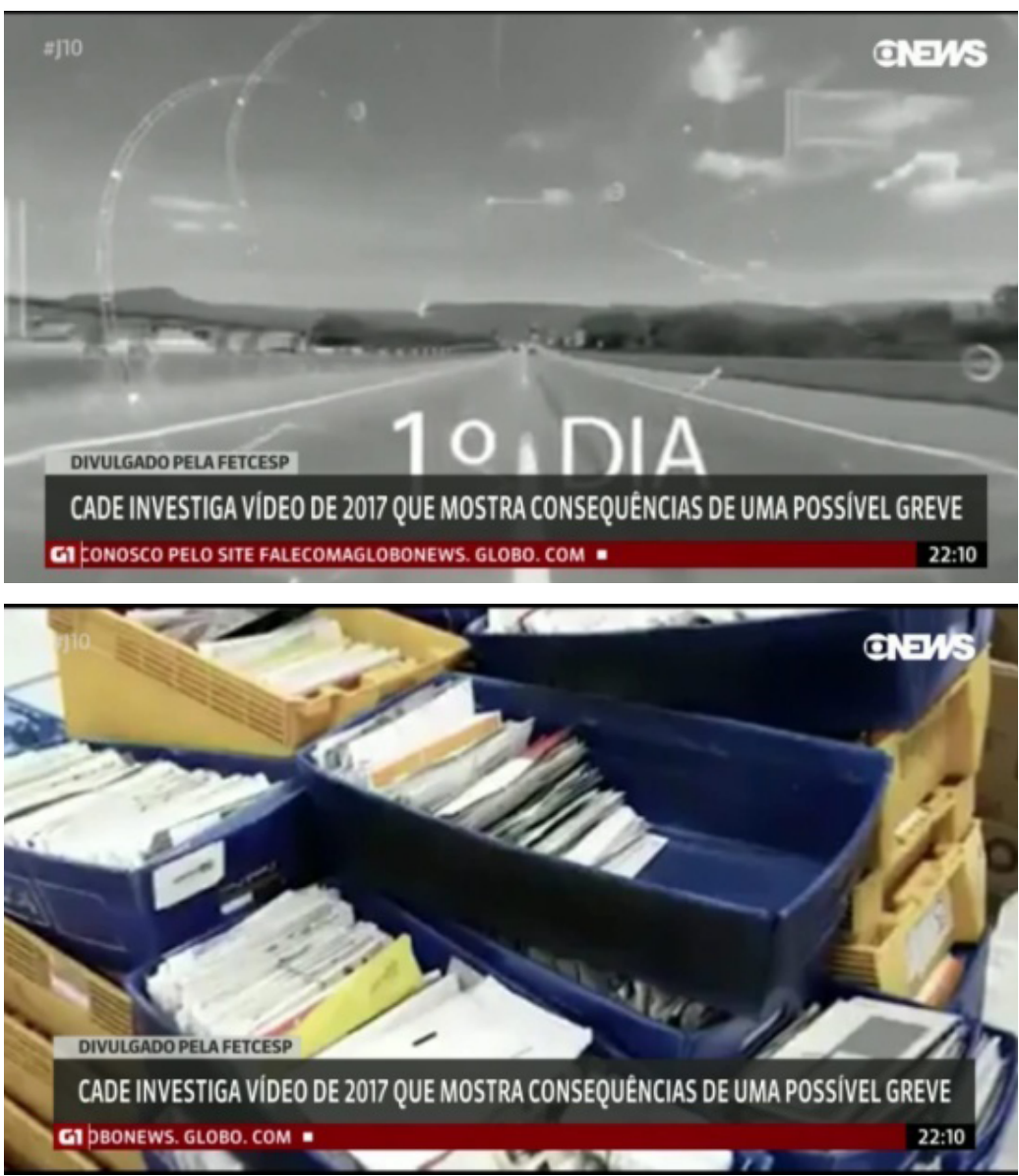

Figura 6. Reportagem mostra trechos do vídeo da FETCESP. Sequência de imagens da GloboNews (2018). 
Outras imagens de caminhões em estradas e postos de combustíveis retiradas do vídeo da FETCESP seguem rodando, enquanto a repórter volta a informar em off: "Ainda no vídeo, a Federação diz que o objetivo era valorizar o transporte rodoviário no Brasil” (GloboNews, 2018). A voz do locutor do vídeo institucional da FETCESP então retorna, sobre imagens de motoristas de carro com sorrisos e fazendo gestos afirmativos com a cabeça, dizendo o que segue: "Muitas vezes reclamamos dos veículos de carga nas estradas e nas cidades, mas esquecemos que eles são as células que transportam tudo o que é vital para termos a vida com que estamos acostumados" (GloboNews, 2018). O vídeo da FETCESP atribui ao narrador um ethos professoral (Maingueneau, 2008a), explicativo, em que ele tenta demonstrar as consequências de uma ausência de caminhões nas estradas. No vídeo original, a ameaça ao desabastecimento de itens essenciais para a vida em sociedade ainda é um elemento eliciador do medo (Damásio, 2000; Ekman, 2011), bem como a oferta de um discurso que tenta mostrar que os caminhões não são um problema, mas sim a solução. Essa intenção, no entanto, ganha um tom de ameaça na releitura argumentativa pretendida pelo governo e incorporada pela matéria da GloboNews. A voz da repórter, então, retorna sobre a imagem de um documento, em que se destaca por computação gráfica a frase "A FETCESP esclarece que não apoia e tampouco incentiva qualquer tipo de paralisação das atividades de transporte rodoviário de cargas" (Figura 7).

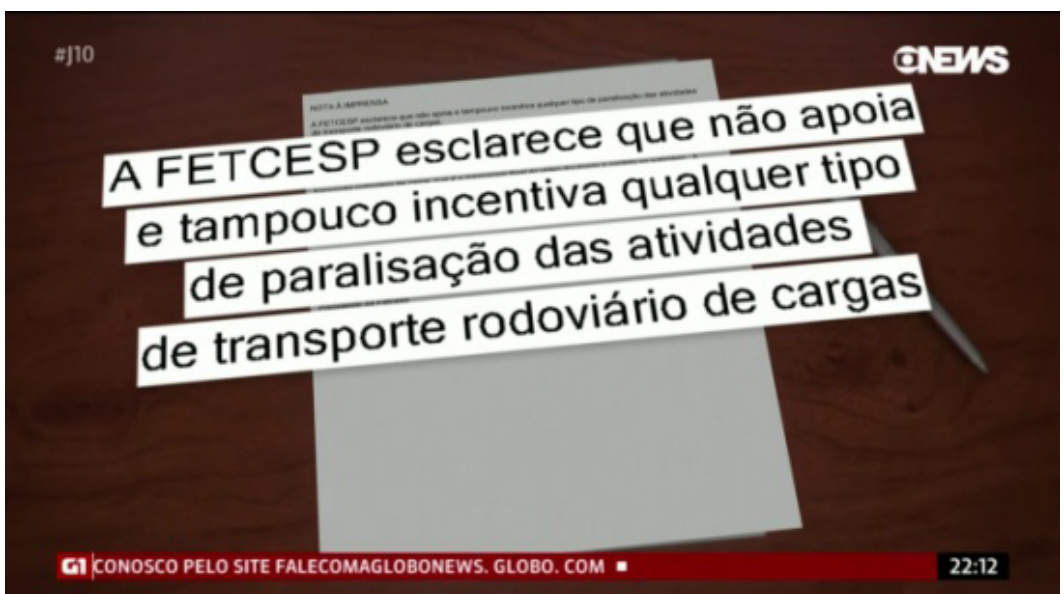

Figura 7. Esclarecimento FETCESP. Imagens da reportagem da GloboNews (2018).

Tal imagem é transposta por uma ilustração gráfica de uma tela de computador, a qual mostra o site da FETCESP. Um efeito gráfico destaca o vídeo institucional mencionado na reportagem, enquanto narra a repórter: 
Diante da repercussão, agora, em nota a FETCESP diz que não apoia e tampouco incentiva qualquer tipo de paralisação das atividades de transporte rodoviário de cargas, e que o vídeo é de maio do ano passado. No site da Federação, o material está em destaque, com o título "conheça o novo filme da FETCESP". O Cade está investigando se houve uma ação coordenada. (GloboNews, 2018)

A reportagem volta a mostrar imagens do prédio do Cade, substituídas na sequência pela imagem do superintendente geral da instituição, Alexandre Cordeiro (Figura 8), que afirma no vídeo: "A gente tem vários fatos que ocorreram e que vêm pra robustecer o processo de investigação. Esse vídeo, ele no mínimo sugere que, se realmente ocorreu a conduta, os agentes sabiam exatamente das consequências dos seus atos" (GloboNews, 2018).

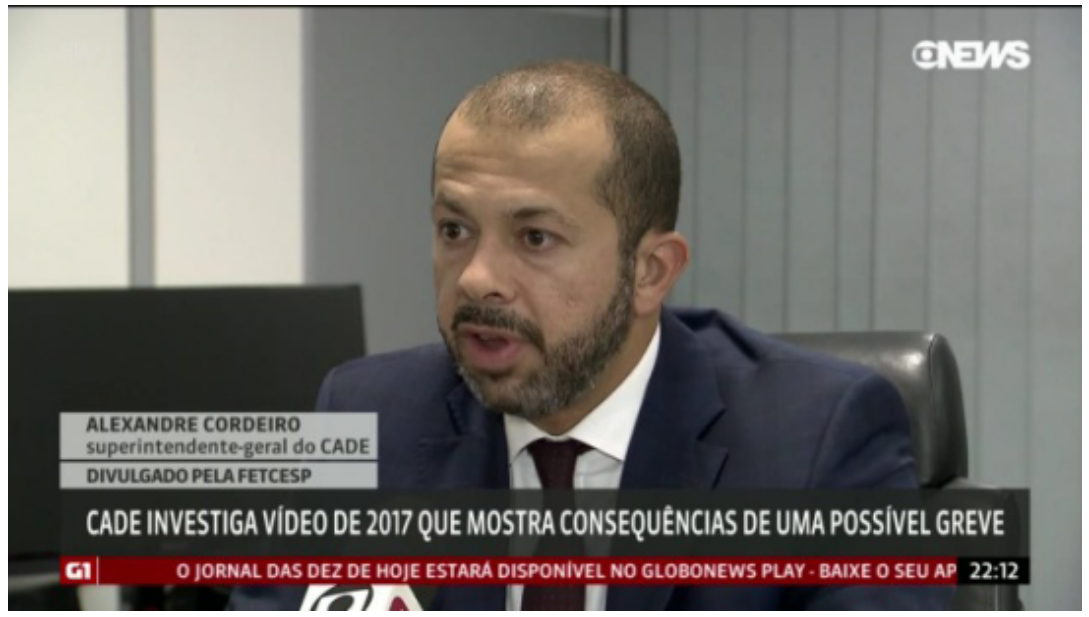

Figura $S$. Superintendente do CADE, Alexandre Cordeiro. Imagem da reportagem da GloboNews (2018).

Cordeiro assume então o papel de fiador do discurso conspiratório do governo. A imagem do superintendente do Cade dá lugar para a passagem da repórter autora do vídeo, Camila Bomfim (Figura 9), que informa:

O governo diz que tem convicção de que houve locaute, ou seja, a participação de empresários na paralisação, o que é proibido por lei. O ministro da secretaria de governo, Carlos Marun, anunciou que empresários suspeitos estão sendo investigados, mas não citou nomes. E disse também que a Polícia Federal já fez até pedidos de prisão que estão sendo analisados pelo judiciário. (GloboNews, 2018) 


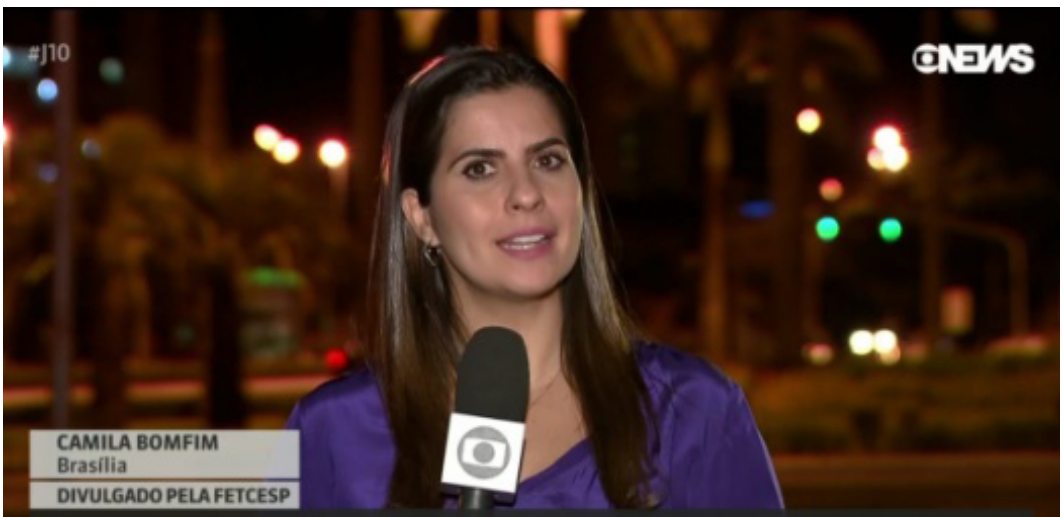

CADE INVESTIGA VIDEO DE 2017 QUE MOSTRA CONSEQUUENCIAS DE UMA POSSIVEL GREVE

G1)E SUGESTOES, CRITICAS OU ELOGIOS, FALE CONOSCO PELO SITE FALECOMAGLOBONEWS. GLOBO 22:12

Figura 9. Repórter Camila Bomfim. Imagem da reportagem da GloboNews (2018).

A imagem da repórter dá lugar então à imagem do ministro da Secretaria de Governo, Carlos Marun, que está em pé, em um púlpito onde se vê ao fundo um painel com a logomarca do Governo Federal e à esquerda da tela uma bandeira do Brasil (Figura 10). Marun diz: "Existem inquéritos. Algumas dessas investigações já justificaram abertura de inquéritos, e... ah... alguns desses inquéritos já trouxeram base sólida, inclusive para que fossem solicitados a prisão (sic)... a prisão de alguns desses... ãããh... suspeitos" (GloboNews, 2018).

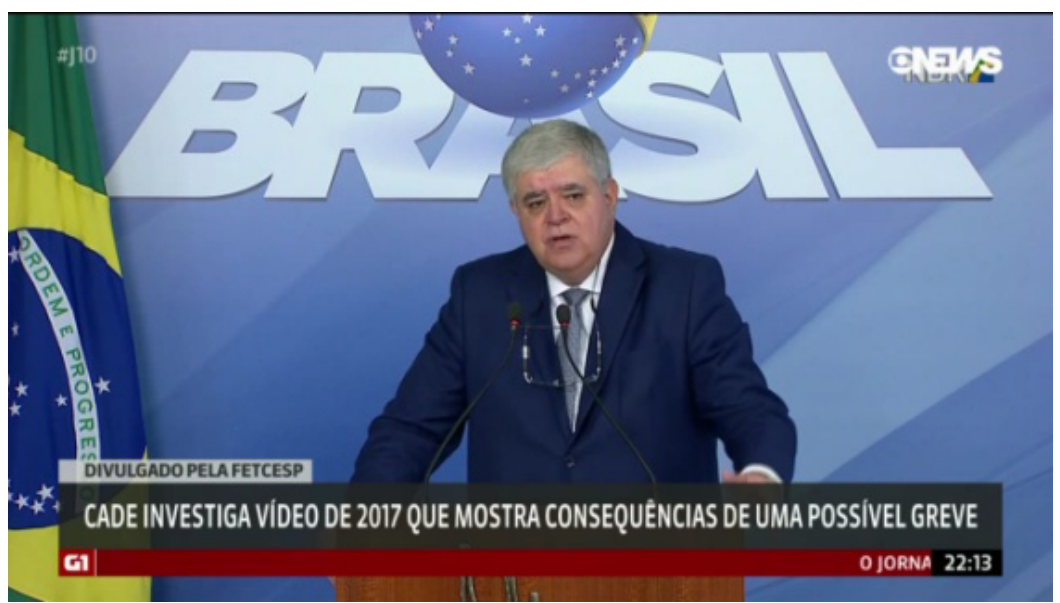

Figura 10. Ministro da Secretaria de Governo, Carlos Marun. Imagem da reportagem da GloboNews (2018). 
A imagem de Marun dá lugar então a imagens do ministro de Segurança Pública, Raul Jungmann (Figura 11), cobertas pela narração da repórter, que segue: "Agora à noite o ministro da Segurança disse que houve apoio criminoso de empresários, e que os suspeitos irão pagar por isso" (GloboNews, 2018). Ao que o próprio Raul Jungmann complementa em depoimento: "Um movimento criminoso de parte dos senhores proprietários, donos de grandes empresas que exatamente não permitem, não engajem, não liberam os seus motoristas. Pelo contrário, né, lhe dão apoio pra permanecer (sic) paralisados" (GloboNews, 2018).

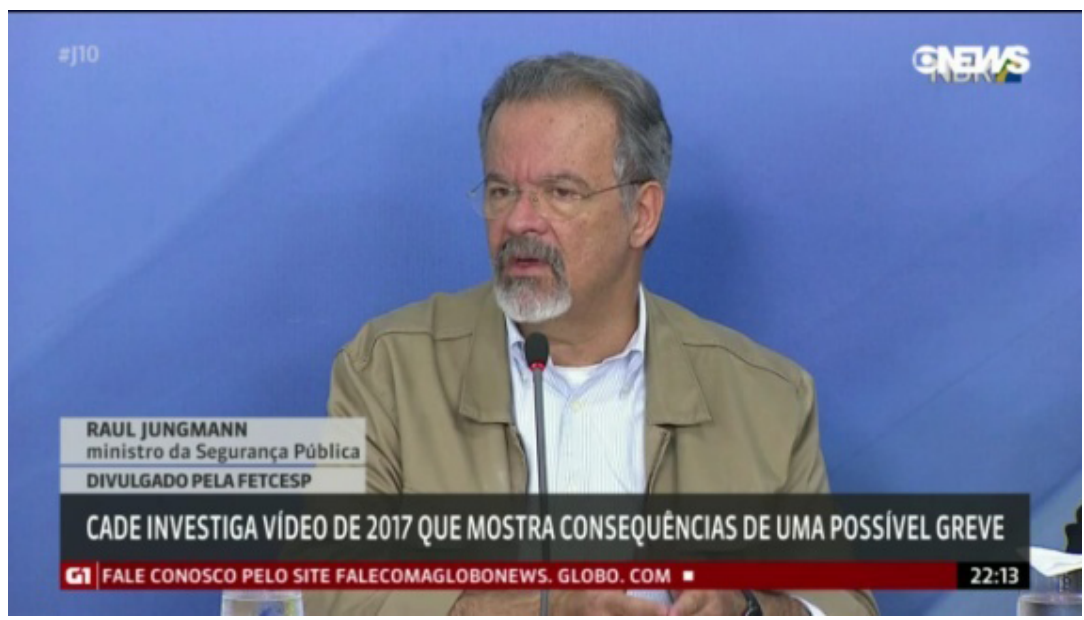

Figura 11. Ministro de Segurança Pública, Raul Jungmann. Imagem da reportagem da GloboNews (201\$).

Após a fala do ministro da Segurança Pública, imagens da sede da Polícia Federal em Brasília são sequenciadas para cobrir nova intervenção da repórter, que finaliza a reportagem: "Até o momento 37 inquéritos foram abertos pela Polícia Federal em 25 estados" (GloboNews, 2018).

As falas dos ministros enquanto porta-vozes do governo carregam um ethos fiscalizador, e denotam um certo endurecimento com os rodoviários. Há uma tentativa de atribuir o fracasso das negociações com as categorias a forças ocultas representadas pela FETCESP e pelo vídeo institucional por ela produzido. Os implícitos da construção intentam classificar a manifestação dos rodoviários como algo imoral, criminoso, que visa objetivos meramente de ganho econômico, ressaltando os pressupostos que norteiam a ideologia da desconexão de Taylor (2006).

Com o fim da reportagem, a âncora do jornal retorna ao vídeo e divide a tela com o comentarista Gerson Camarotti, que aparece em um telão no estúdio 
do jornal (Figura 12). Camarotti é convidado a comentar o vídeo, e seu discurso endossa a visão conspiratória do governo, como nos trechos em que diz

Você tem ali é todo um cronograma... quase que um efeito... é... de terrorismo psicológico no país. Você tem ali no primeiro dia, como seria, o segundo dia, o terceiro dia, o quarto dia, o quinto dia. E tudo aconteceu e já estamos no sexto dia. (GloboNews, 2018)

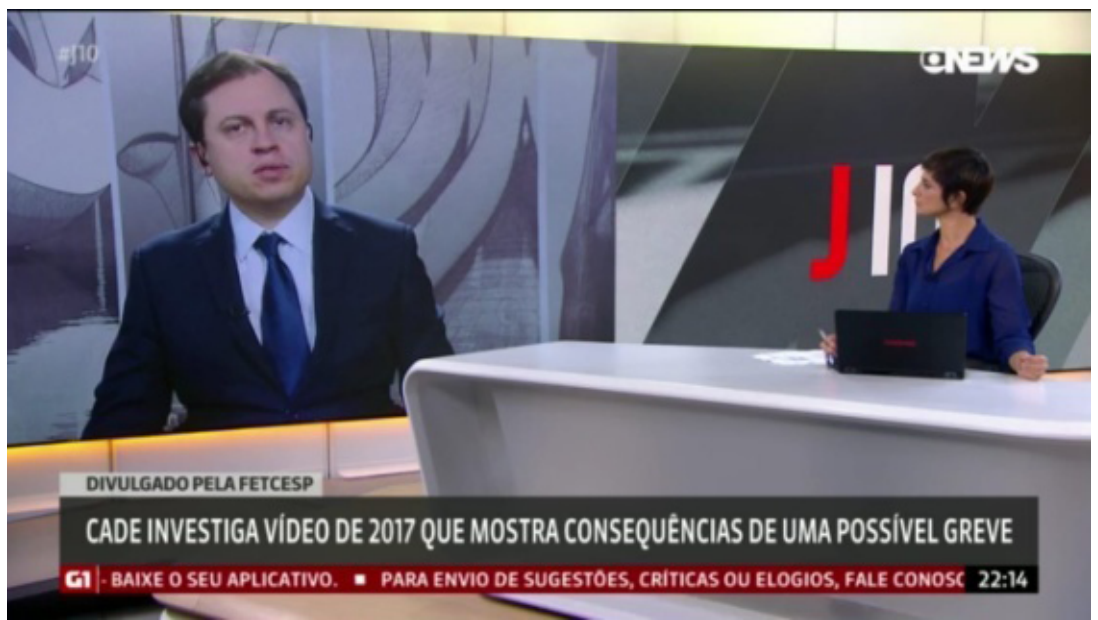

Figura 12. Gerson Camarotti comenta reportagem. Imagem da reportagem da GloboNews (2018).

Em outro trecho, o comentarista acrescenta "Então, você tem ali não só entidades como grandes empresários, e o governo, a gente acabou de ver na reportagem, de fato, tem uma convicção de que essa mobilização chegou até aqui com tanta força, exatamente pelo suporte empresarial" (GloboNews, 2018). Camarotti se vale do ethos de comentarista de política e economia do telejornal para validar a cena proposta pelo Governo Federal.

Tal deslocamento enunciativo revela a premissa da ideologia da desconexão de Taylor (2006), quando elicia a força da moral sobre os interesses econômicos dos empresários do setor rodoviário, numa tentativa de deslocar os rodoviários do papel de vítimas de uma política de preços, considerada por eles como abusiva, para o papel de vilões responsáveis pelo caos resultante da paralisação. Ao mesmo tempo, fica implícita uma tentativa de ressignificação (Bateson, 1987; Dilts, 2014; Peirce, 2008) a respeito da responsabilidade do Governo Federal em relação à política de preços aplicada pela Petrobrás, que fez disparar o preço do óleo diesel, fator que originou os primeiros protestos dos caminhoneiros. 


\section{CONSIDERAÇÕES FINAIS}

Após revisitar conceitos acerca dos processos de significação, e de como esta significação estrutura crenças que vão coexistir e interagir com o imaginário coletivo carregado de ideologia, tomamos como base alguns princípios da ideologia da desconexão (Taylor, 2006) como norte para identificá-la nas construções discursivas da cobertura jornalística da GloboNews sobre a greve dos caminhoneiros. Usando elementos da análise de discurso de Maingueneau (2008a, 2008b, 2013), no que se refere a cenografia e ethos, constatou-se que a reportagem da GloboNews direciona a percepção de que o ethos discursivo dos atores envolvidos no construto midiático é apoiado em cenografias enunciativas que eliciam o medo para gerar aderência do público aos ethè em disputa. De certa forma, a construção jornalística analisada funciona para ressignificar a paralisação dos caminhoneiros a partir de uma fonte de poder, no caso o Governo Federal, a ponto de ser classificada, mesmo que implicitamente, de conspiratória, o que é aceito sem objeção ou questionamento por parte dos construtores da notícia, algo que não corresponde ao ethos discursivo do jornalista.

O caso nos mostra que a ideologia da desconexão é o motor dos discursos dos fiadores e dos atores convidados à cena enunciativa, ora recorrendo aos números, ora recorrendo à moralidade, para que seus interesses sejam percebidos como legítimos por parte do espectador.

O tom conspiratório, de que as paralisações foram orquestradas por forças patronais, está presente ao longo de toda a reportagem, no discurso da jornalista da matéria, na fala dos ministros e agentes que investigam o caso, e na fala do comentarista que endossa a conclusão do Governo Federal como uma cena validada. Os entrelaçamentos teóricos propostos no artigo, portanto, dão margem ao entendimento que a aderência ao ethos, às cenas de enunciação e às ideologias é permeada por tentativas de eliciações emocionais que serão determinantes nos processos de significação dos sujeitos. M

\section{REFERÊNCIAS}

Amossy, R. (Org.). (2011). Imagens de si no discurso: A construção do ethos (2a ed.). São Paulo, SP: Contexto.

Antunes Junior, F. S. (2016). A retórica do medo: Uma análise neurolinguística da mídia (Tese de doutorado). Pontifícia Universidade Católica do Rio Grande do Sul, Porto Alegre, RS. Recuperado de https://bit.ly/33XNZSv

Bandler, R., \& Grinder, J. (2004). A estrutura da magia. São Paulo, SP: Summus. 
Bartolli Filho, C. (2012). Novas doenças, velhos medos: A mídia e as projeções de um futuro apocalíptico. In Y. N. Monteiro, \& M. L. T. Carneiro (Orgs.), As doenças e os medos sociais (pp. 13-36). São Paulo, SP: Fap-Unifesp.

Bateson, G. (1987). Natureza e espírito: Uma unidade necessária. Lisboa, Portugal: Publicações Dom Quixote.

Bauman, Z. (2009). Confiança e medo na cidade. Rio de Janeiro, RJ: Zahar.

Colapietro, V. M. (2014). Peirce e a abordagem do self: Uma perspectiva semiótica sobre a subjetividade humana. São Paulo, SP: Intermeios.

Damásio, A. (2000). O mistério da consciência: Do corpo e das emoções ao conhecimento de si. São Paulo, SP: Companhia das Letras.

Dilts, R. (2014). A brief history of logical levels. Santa Cruz, CA: NLP University. Recuperado de https://bit.ly/2UxT5S6

Ekman, P. (2011). A linguagem das emoções. São Paulo, SP: Lua de Papel.

Federação dos Transportadores de Carga do Estado de São Paulo. (2017). O que aconteceria se os caminhões sumissem durante 5 dias? [arquivo de vídeo]. Recuperado de https://bit.ly/2RS5Zsx

Ferrés, J. (1998). Televisão subliminar: Socializando através de comunicações despercebidas. Porto Alegre, RS: Artmed.

Giddens, A. (1989). A constituição da sociedade: Consciência, self e encontros sociais. São Paulo, SP: Martins Fontes.

GloboNews. (2018, 26 de maio). Cade investiga vídeo de 2017 que mostra consequências de possível greve de caminhoneiros [arquivo de vídeo]. Recuperado de https://glo.bo/3dFFcc6

Greve dos caminhoneiros: a cronologia dos 10 dias que pararam o Brasil. (2018). BBC News Brasil. Recuperado de https://www.bbc.com/portuguese/brasil-44302137

Lent, R. (2008). Neurociência: Da mente e do comportamento. São Paulo, SP: Guanabara Koogan.

Maingueneau, D. (2008a). Cenas da enunciação. São Paulo, SP: Parábola.

Maingueneau, D. (2008b). Gênese dos discursos. São Paulo, SP: Parábola.

Maingueneau, D. (2013). Análise de textos de comunicação. São Paulo, SP: Cortez.

Peirce, C. (2008). A fixação da crença. São Paulo, SP: Ideias \& Letras.

Silva, C. (2018, 31 de maio). Greve de caminhoneiros deixa rastro de prejuízos bilionários em todo o País. Estado de S. Paulo. Recuperado de https://bit.ly/2Uyezi1

Taylor, M. (2006). Rationality and the ideology of disconnection. Cambridge, Inglaterra: Cambridge University Press.

Volóchinov, V. (2017). Marxismo e filosofia da linguagem: Problemas fundamentais do método sociológico na ciência da linguagem. São Paulo, SP: Editora 34.

Artigo recebido em 18 de fevereiro de 2019 e aprovado em 25 de março de 2020. 